\title{
КОНЦЕПТ БАЛКАН У САВРЕМЕНОМ СРПСКОМ ЈЕЗИКУ И КУЛТУРИ (НА МАТЕРИЈАЛУ АНКЕТНИХ ПОДАТАКА)
}

Предмет овог рада је лингвокултуролошка анализа појма Балкан. Истраживање је спроведено на основу асоцијативних података до којих се дошло применом анкетног испитивања. Циљ истраживања је да се пружи један од могућих увида и прегледа о томе како се у савременом дискурсу говорника српског језика концептуализује појам Балкан. Показало се да је он у свести говорника српског језика дефинисан врло поларизовано и да разлоге томе треба тражити примарно у ванлингвистичким факторима који дефинишу српску културу.

Кључне речи: српски језик, лингвокултурологија, анкета, вербалне асоцијације, Балкан.

\section{1. О Балкану}

У хронологији именовања, назив Балкан се првобитно односио на планински ланац, познатији по грчкој варијанти свог имена - Хемус (Тодорова 1999: 47-50; Мазовер 2003: 23; Мутавџић 2013: 47). Порекло ономастикона који познајемо данас везује се за турску етимологију. Подаци показују да је карактеристични назив за Балкан с почетка нове ере био и Централни масив, име које ће се у одређеном степену присуства одржати све до ренесансе и просветитељства, након чега ће бити оповргнуто због нетачног географског одређења под којим се дати простор подразумевао (Мутавџић 2013: 47). Закључно са Берлинским конгресом, западна Европа ће Балканско полуострво превасходно познавати као Турску у Европи, Европску Турску, Царство великог Турчина и томе слично (Тодорова 1999: 55; Мазовер 2003: 24-25; Ibid.). Све ово не значи да само име

\footnotetext{
* Универзитет у Београду, Филолошки факултет, Студентски трг 3, 11000 Београд; milica_skoric@ymail.com
} 
Балкан раније није употребљавано. Према историјским изворима, италијански дипломата и писац Филип Калимах (у изворима и Филипо Калимако) спомиње овај назив у меморандуму који је 1490. године послао папи Иноћентију VIII, реферишући на масивни планински венац у средишњој Бугарској (Тодорова 1999: 47; Мутавџић 2013: 48). Временом ће, уласком у 20. век и падом османске владавине, уз подељену оцену о таквој пракси, простор југоисточне Европе бити називан Балканом, тј. Балканским полуострвом, што је било директна последица политичких промена, када се има у виду назив Турска у Европи. Након Другог светског рата термин Југоисточна Европа сматраће се неприхватљивим с обзиром на злоупотребу овог термина од стране нациста (Тодорова 1999: 57 58). У разноликим тумачењима се простор југоисточне Европе географски третирао и као регион који је шири у односу на онај који покрива Балкан. Оно што је недвосмислено јесте да се, са новим друштвеним изменама, отварао простор у којем ће Балкан све више добијати политичку конотацију, и стицати услове да се, лингвистички, одваја од феномена који само именује, али не означава. Политичко интерпретирање појма који лексема Балкан означава кретаће се, по правилу, кроз сферу негативне оцене, па отуда енглески путописац и истраживач Хари де Винт још 1907. говори о дивљој Европи, простору омеђеном Јадранским и Црним морем као стециштем безакоња, примитивизма и насилништва (Мазовер 2003: 26). До Другог светског рата у такав наратив ће се уклопити и садржаји из домена уметности, те ће се у сфери књижевности и филмографије простор Балкана искористити за позорницу на којој ће се приказивати сценарији о насиљу и злочинима (нпр. Агата Кристи у роману Тајна димњака или Жак Турнер у свом филму Људи мачке) (Ibid., 27). Оваква оцена „Запада” о Балкану утихнуће у периоду Хладног рата, а вратиће се са колапсом комунизма и наново кулминирати са распадом СФРЈ (Ibid., 28). Балкан и његови чланови деривационог гнезда попут лексема балкански и балканизащија заћи ће у домен експресивизације непожељног. Сам термин балканизација у првој половини 20. века имао је своје већином неутрално политичко значење које се односило на цепање и распарчавање територија, међутим у новије време, овај термин ће и квантитативно и квалитативно ширити свој семантички обухват, чиме ће његов политички смисао имати пун ослонац у пејоративном (Тодорова 1999: 64-71; Мутавџић 2013: 20-21). Отуда, прецизно дефинисати и разумети Балкан значи ослонити се на разноврстан број како географских тако и политичких, културних, историјских критеријума, често кроз призму њиховог међусобног комбиновања. Једно од питања онда последично може бити и како лингвистика гледа на појам обухваћен лексемом Балкан. 


\section{2. О култури}

Појам културе у друштвено-хуманистичким наукама различито се интерпретира услед разноврсних атрибутивних својстава која јој се додељују, и различитих полазних позиција наука̄ и дисциплина̄ у односу на које се феномен културе истражује. Кребер и Клакхон у својој критичкој студији о концептима и дефиницијама културе наводе преко 250 дефиниција, уопштавајући их у шест категорија - описне, историјске, нормативистичке, психолошке, структуралне и генетичке (Кребер и Клакхон 1952: 41-78). За потребе овог рада, култура ће се посматрати као једна од многобројних дескриптивних категорија једног друштва и имаће ослонац у дефиницији коју даје Ранко Бугарски (Бугарски 2005: 7) - култура је „систем за организовање и усмеравање људског искуства, при чему поједине културе на различите начине упрошћавају [...] укупни свет стварности. Тако свака култура образује специфичан оквир унутар којег се интерпретирају одабрани спољни знаци реалности". За интерпретацију такве стварности човек као основни механизам користи језик, који са културом опстаје у сталном напону узајамног деловања.

\section{3. О лингвокултурологији}

У последња два века лингвистика је пролазила кроз смену различитих парадигми. Током друге половине 19. века, на трагу развитка позитивистичких учења, језикословну делатност је захватио талас нових теоријских поставки, које су своје утемељење тражиле у чињеницама и направиле отклон од дотадашњег третмана знања о језику из угла метафизичких концепција и филозофије уопште. Тада се појављују младограматичари, који су у лингвистичке теоријско-методолошке оквире донели компаративно-историјски метод (Ивић 2001: 71, 73). Појавом Фердинанда де Сосира, у 20. веку се као нова научно-истраживачка парадигма јавља структурализам. У основи је структуралистички приступ био синхронијски, језик је био третиран као сложен систем саздан од подједнако комплексних структурних релација, које су уједно и основни предмет истраживања структуралиста (Ibid., 153154). С краја 20. века фокус се премешта са објекта на субјекат, што погоди развоју антропоцентричке језичке парадигме. Као и свака нова, и ова парадигма је утицала на развој нових лингвистичких дисциплина, и то у првом реду когнитивне лингвистике, која језику прилази као когнитивном феноме- 
ну, и лингвокултурологије, дисциплине коју језик као предмет истраживања интересује у релацији са културом. Оснивачима ове дисциплине сматрају се Арутјунова, Воробјев, Маклеин, Маслова, Степанов и Телија, а сам термин лингвокултурологија се у српским научним круговима почео јављати у радовима Ксеније Кончаревић, Твртка Прћића, Рајне Драгићевић и др. (Вуловић 2015: 14). Лингвокултурологија изучава манифестације културе одређеног народа, и то оне које су своју стабилност и одраз пронашле у језику самом. У фокусу се сада налазе човек као субјекат и начин на који се он и језик односе једно спрам другог (Драгићевић 2010а: 7). Контексти за дефинисање сазнајних структура у прве две парадигме артикулисали су се првенствено у језику самом, док су две нове дисциплине, вођене антропоцентричким тумачењима, значај контекста нужно почеле тражити и ван језичког система.

\section{4. Лингвокултурологија и однос са другим дисциплинама}

Када се лингвокултурологија почела осамостаљивати, отворило се питање њеног односа са етнолингвистиком. Према речима Рајне Драгићевић, која се у својим истраживањима позива на руске фразеологе, лингвокултурологија је део етнолингвистике. Дистинкција се прави на временској равни, тиме што етнолингвистика има статус дијахронијске дисциплине, а лингвокултурологија статус синхронијске (Ibid., 9). Никита Толстој етнолингвистику у ужем смислу дефинише као дисциплину која „изучава језик у светлости његовог односа са етносом”, интересујући се за „одразе културних, народно-психолошких и митолошких представа и 'преживљавања' у језику" (Толстој 1995: 31, 45), Тако схваћена, етнолингвистика би обухватала лингвокултурологију. У ширем смислу она се усложњава и - тиме што за предмет нема нужно језичку јединицу, већ се интересује за различите форме друштвеног општења, као што су обреди или веровања - постаје сложена самостална грана науке (Ibid., 46). Један од главних представника руске етнолингвистичке методологије је Биљана Сикимић (2005, 2006 [2007], 2012), док је у комбинацији са другим методама она присутна у научном раду Марте Бјелетић, Јасне Влајић-Поповић, Александра Ломе, Мирјане Детелић и Љубинка Раденковића (в. Илић 2002; Драгићевић 2010а: 9; Илић и Ђурић Миловановић 2013)). Јежи Бартмињски, етнолингвиста и лингвокултуролог, који предводи лублинску етнолингвистичку школу, своје виђење предмета етнолингвистике изједначава са изоморфним односом језика и културе, заинтересован за то како се култура оваплоћује у језику. Основни циљ његове 
методологије јесте долазак до когнитивне дефиниције, тј. добијање одговора „на питање о начину поимања предмета од стране говорника датог језика, тј. о начину (друштвено утврђеном и доступном проучавању кроз језик и употребу језика) стицања знања о свету, категоризације његових појава, њихове карактеризације и вредновања" (Бартмињски 2011: 93). Поред когнитивне дефиниције, Бартмињски као основне појмове свог когнитивно-етнолингвистичког приступа издваја и језичку слику света, стереотипе као фрагменте дате слике и субјекта који, заузимајући одређену тачку гледишта, концептуализује, процењује и евалуира стварност. Отуда се језичка слика света може схватити као субјектово интерпретирање стварности у виду колективних представа (стереотипа), изражено вербалном компонентом, а профилисано кроз субјектов систем усвојених вредности и угао посматрања реалног (Ibid., 68). Према Бартмињском, предмети поља истраживања и етнолингвистике и лингвокултурологије толико су једни другима слични да их „сам аутор истозначно употребљава, што се нарочито види у представљању програма ЕУРОЈОС-а и најважнијег задатка овог програма, израде Аксиолошког лексикона Словена и њихових суседа" (Ристић и Лазић Коњик 2020: 25). У србистици се развијају различити приступи под утицајем лублинске етнолингвистичке школе у радовима Дејана Ајдачића, Рајне Драгићевић, Стане Ристић, Марије Стефановић и других. (Ibid., 16). Лингвокултуролошки приступ негују Рајна Драгићевић (2010в, 2011, 2014, 2017) и Слободан Новокмет (2020). Лингвокултуролошка синхронијска истраживања заснована на техници прикупљања података у виду анкете (према методи Бартмињског) и квалитативној анализи вербалних асоцијација, поменута ауторка примењује у својим истраживањима о концептима слобода, Исток, Запад и другим, и то ће уједно бити теоријско-методолошки оквир за спровођење овог истраживања (Драгићевић 2015a, 2015б).

За лингвокултурологију је важан и њен однос са лексикологијом. Културалне семе (или тзв. семе колективне експресије према терминологији Даринке Гортан-Премк) налазе се у оквиру лексемске конотације, која је, с друге стране, један од важних сегмената лексичког значења. Отуда је за лексиколога (и лексикографа свакако) исто колико и за лингвокултуролога важно да се бави слојевима културалних конотација (како их је именовала Маслова) и за њима трага (Драгићевић 2010a: 11). С друге стране, није од примарног значаја за лингвокултуролога да анализира и значење лексеме, али то свакако не значи да то не може бити један од многобројних приступа у анализи грађе. Према истраживањима која је спровела Милка Ивић, а 
на која се позива Рајна Драгићевић, руска лингвокултурологија погрешно тумачи да култура утиче искључиво на конотацију, већ се њен утицај може пробијати и до саме денотације одговарајуће лексеме, што је од значаја у компаративним и контрастивним истраживањима (Ibid.).

Са свиме досад споменутим, ваља истаћи да лингвокултуролошки приступ у србистици не мора бити присутан искључиво у анализама које обухватају лексички ниво стандардног језика. Тања Милосављевић са Института за српски језик САНУ бави се и дијалекатском лингвокултурологијом (Милосављевић 2021), а у радовима Драгане Мршевић-Радовић, Наташе Вуловић и Ане Пејановић лингвокултуролошка испитивања се врше и на фразеолошком материјалу (Мршевић-Радовић 2008; Вуловић 2015; Пејановић 2015).

\section{5. Теоријско-методолошке поставке}

Ванлингвистички фактори који махом задиру у сферу друштвених, превасходно политичких промена могу бити значајни за семантику речи чија је основна функција именовање. Конотативни ниво таквих јединица је самим тим испражњен. Међутим, са упливом утицаја које горепоменути фактори могу индуковати у лексикон, уочено је како одређен број властитих именица може бити разумеван и из угла лингвокултуролошке сфере језика и обитавати у њој као језичка јединица сада заснована не само на именовању већ и на означавању. Основни циљ овог рада је испитати како се Балкан као лингвокултурема одговарајућег појмовног садржаја може конфигурисати у језичкој свести говорника српског језика као носилац конотативних вредности. ${ }^{1}$ Ауторкина идеја јесте да, примењујући анкетну технику прикупљања података и метод вербалних асоцијација које ће потом квалитативно бити анализиране, пружи тек један од могућих увида у то како говорници српског језика у својој свести концептуализују Балкан и како се он позиционира у њиховом емоционално-вредносном систему. Према методологији коју, преузимајући је од Бартмињског, у својим лингвокултуролошким радовима примењује Рајна Драгићевић, до скупа жељених судова стиже се обрађивањем трију типова података - системских (подаци из речника), анкетних (подаци добијени анкетирањем) и текстуалних (подаци из књижевних дела, штампе, електронских медија и слично). За потребе овог рада ауторка ће се

1 Термин лингвокултурема у појмовни апарат лингвокултурологије увео је Воробјев (Маслова 2010: 51-53). Она као сложена „међустепена јединица представља дијалектичко јединство лингвистичког и екстралингвистичког (појмовног или предметног) садржаја" (Вуловић 2015: 228). 
бавити само анкетом, чија ће функција бити да прикупи асоцијације које испитаницима прве падају на памет када се спомене Балкан у одговарајућим синтагматским и реченичким контекстима. Један од разлога зашто резултати овог рада неће бити третирани као уопштавајући лежи у чињеници да нису исцрпљене све методе ни технике којима се истраживач могао послужити да би покрио више углова, који би могућно произвели хетерогеније резултате и тиме били од користи за укупну оцену. Други разлог се тиче самог избора испитаника. Групу испитаних чини популација у својим двадесетим и тридесетим годинама, те узорак не може бити репрезентативан да би се резултат уопштио на целокупну популацију. У ту сврху би варијабла годишта морала бити садржајнија, а само испитивање квантитативнпо ширег обухвата. Ономастикон је инспиративан за истраживање јер примарно у себи не садржи функцију означавања у односу на лексеме као што су, на пример слобода, љубав или бол. Па ипак, са Балканом се то управо дешава, те се сматра да је за потребе овог рада битно осветлити један од могућих углова интерпретације Балкана као јединице од лингвокултуролошког значаја.

Анкетно истраживање се у друштвеним наукама дефинише и као техника прикупљања података и као метод, а сам однос ова два се може посматрати као преклапање у одређеним условима. У ширем контексту гледано, могло би се рећи да анкета постаје методом у оном случају када је „циљ уопштавање података добијених на узорку на популацију у целини, тј. закључивање о популацији" (Попадић, Павловић и Жежељ 2018: 276). У складу са већ споменутим разлозима, резултати овог истраживања имају логичка и техничка оправдања због који не могу бити схваћени као подаци подложни генерализацији на нивоу целокупне нације. Једна од техника анкетних истраживања јесте упитник. Угрубо, његова подела се углавном темељи на постојању класичног или експлоративног упитника (што је случај са овим истраживањем) и скале процене. ${ }^{2}$ Класични упитник тежи да укључи питања различитих форми и садржаја не би ли се омогућило адекватно испитивање жељеног феномена и аспеката који га чине, а који потенцијално могу међусобно ступати у одређене везе (Ibid., 280). Подаци прикупљени овим упитником јесу квалитативне природе, па ће им се самим тим приступити из угла дескриптивне квалитативне обраде. Квантификација ове врсте података има секундарни значај, али може допринети у оној мери у којој ће омогућити јаснији преглед грађе тиме што пребројава учесталост одговора у узорку.

2 Класични упитник је у зависности од техничких услова испитаницима био представљен или директно или у онлајн форми. 
Основни задатак предочен испитаницима у овом истраживању био је да на постављена питања одговарају без много премишљања и садржајем који им први пада на памет, и на који их асоцира образац самог питања. Циљ је био доћи до примарних асоцијација на задати појам. Метод вербалних асоцијација је у србистичкој лексикологији до сада свој најшири обухват примене добио у Асоцијативном (2005) и Обратном асоцијативном речнику српскога језика (2011), који је настао као резултат првог. ${ }^{3}$ Систем у којем се метод примењивао захтевао је од испитаника да на реч-драж, односно реч-стимулус, коју види пред собом одговори у најкраћем року својом првом асоцијацијом, тзв. речју-реакцијом. Тај захтев је за потребе овог истраживања у прилагођеном облику уграђен у структуру упитника састављеног за говорнике српског језика. Један од запаженијих резултата асоцијативна метода је остварила у испитивању стереотипа̄, пружајући актуелне увиде у перцепцију говорникове стварности и у све потенцијалне промене тих перцепција (Драгићевић 2010б: 111). У зависности од очекиване форме одговора, испитаници су у овом истраживању пружали податке у виду и дискретних (захтев да се одговори једном речју) и континуираних асоцијација (очекивање да се на задату реч или конструкцију одговори већим бројем речи). Такође, истраживачки захтев је у одређеним питањима био да се одговори одређеном врстом речи, што је за последицу давало резултат у виду контролисане асоцијације.

\section{6. Анкетни подаци о Балкану у српском језику}

Као што је споменуто, анкетирање представља један од значајних истраживачких процеса за проблематику овог рада јер, пружа увид у сложеност уобичајене представе Балкана кроз призму савремених друштвених токова. Групи од 114 говорника српског језика затражено је да одговори на шест питања, од којих прво бива у складу са упутствима етнолингвисте и лингвокултуролога Јежија Бартмињског о формирању одговарајуће базе података посредством упитника. ${ }^{4}$ Остала питања осмишљена су са идејом да би их

3 Више о историјату асоцијативне методе в. Драгићевић 20106: 96-125, а о примени асоцијативне методе у сврху анализе података о лингвокултуролошког значаја в. Драгићевић 20106: 99-147.

4 За потребе истраживања формиран је један од типова неслучајних узорака - пригодни узорак. Пошто циљ није да се карактеристике узорка генерализују на целокупну популацију, сматра се да је овај вид узорка одговарајући. Њега су чинили говорници оба пола српске националности, рођени на различитим територијама Србије и бивше СФР Југославије. Медијана њихове старости износила је 28 година. Истраживање је спроведено у Београду посредством директног и онлајн анкетирања у јуну 2021. године. 
требало прилагодити форми потенцијалних одговора који ће својим садржајем допринети разумевању концепта Балкан. Важно је нагласити да број одговора није увек једнак 114, јер су испитаници понекад или давали већи број одговора или нису давали одговор на одређено питање (уопште или у граматичкој форми која је захтевана). ${ }^{5}$

Питање број 1. У првом питању испитаници су замољени да одговоре шта, према њиховом мишљењу представља суштину правог Балкана. Идеја је била да испитаници посредством свог одговора пруже пример властите дефиниције. Формулација овог питања гласила је: „Шта, према Вашем мишљењу, представља суштину Балкана, тј. шта бисте сматрали његовом правом дефиницијом?” Чињеница да су се неки одговори понављали у идентичним или сличним формулацијама одговара устаљености значења речи у свести говорника, те се посредством ње успоставља и однос према појму. Одговори су најчешће бивали уобличени као реченице у оквиру којих су испитаници износили више различитих чињеница које су сматрали релевантним. Ради лакшег прегледа, успостављене су неке квалитативне дистинкције које шире појмовно обухватају дати садржај. ${ }^{6}$ У питању су следећи аспекти:

ГЕОГРАФСКО ОДРЕЪЕЊЕ: Полуострво (27), део ЕвроПе, део југоисточне Европе (3), Србија (2); простор јужно од Соче, Саве и Дунава до мора, одличан географски положај, иентар, капија Европе, територија сродних народа, регија, раскрсница светских путева (1).

КУЛТУРОЛОШКО-РЕЛИГИЈСКО ОДРЕЪЕЊЕ: мноштво различитих вера, култура, народа и нација (22); спој Запада и Истока (7); буре барута (4); традиционализам (3); ветрометина, словенска душа, колевка европске цุивилизације, модернизам, немодерност, култура, простор на раскрићу, спој хриићанских и оријенталних елемената, суживот различитих вера на једном месту, конзервативизам (1).

ОСОБИНЕ И СТАҢА: Гостопримство (4), менталитет (3), инат (2), дружељубивост, добродушност, забавно, веселост, лепота, слога, препун љубави, а незалечених траума, сељаштво, осећајност, бурност реакичја, отпор-

5 Као пример одговора који су формално изузимани истичу се они из шестог питања, где је требало да говорници наведу инфинитивни облик глагола који би употребили у поредбеној конструкцији ”, као на Балкану". Неки од таквих изузетих (и нефреквентних) одговора били су: нигдје; све је; леп живот; брдовит; тешко; ито јужније, то тужније; исти; срећан; лудост; лепота.

6 Ради анализе добијених одговора, грађа је разврстана према појмовним одредницама које обухватају одређену семантичку сферу, а те одреднице су кроз рад истакнуте великим словима. 
ност, срчаност, туга, затуцианост, отвореност, срдачност, сујета, незрелост, Понос (1).

Највећи број добијених одговора указује на то да говорници Балкан првенствено доживљавају као полуострво, што је секундарно значење ове лексеме према подацима из РСJ.7 Један од могућих разлога за ово се може тражити у пракси масовних медија, посредством којих је у свакодневници људског искуства најпре изражен политички аспект, а у којем се овим именовањем, у географском контексту, алудира на полуострво; притом, не нужно експлицитно, већ у значењу које ће подразумевати шири географски простор на којем живе различити народи. Односно, уколико би се подразумевало да је Балкан у значењу полуострва кондензована варијанта поникла на законима језичке економије и метонимијског преноса (Балкан $<$ Балканско полуострво), имплицитан семантички садржај који се жели формулисати налазио би се управо у одговору који је други по фреквенцији у асоцијацијама испитаника, преломљен кроз историјску призму и њене културолошко-религијске аспекте. Отуда се Балкан персонификује као мноштво друштвених различитости, чијих је носилац човек. Такав човек је, судећи по упитнику, првенствено гостољубив, у свести говорника најчешће поларизован између низа пожељних особина (модеран је, дружељубив, весео, добродушан, осећајан, срдачан и отворен према другима) и непожељних (није модеран, истраумиран је, тужан, незрео, примитиван и сујетан). Јаснији увид у особине стиче се у одговорима на наредна питања, но тек, за ово питање је важно што се на самом почетку види да лексема Балкан у свом конотативном домену евидентно бива носилац сема колективне експресије, да сада има функцију и именовања и означавања, да се често огледа у персонификацији, те да она није доследно једноличних атрибута. Балкан као експресивна лексема није предмет ово рада, али би због поменутих особина могао бити плодно тло за анализе у том смеру (Ристић 2004). Његова позиција у свести људи изражено је аморфна. Отворено је питање у којој мери заправо српски језички представник, када каже Балкан, мисли Србија. Судећи по истраживању које је спровела Рајна Драгићевић, испитујући концепте Истока и Запада, на основу података из упитника, говорници Србију пре сврставају у Исток, међутим, по резултатима добијеним из текстова новинарског функционалног стила, Србија је управо ,разапета” између Истока и Запада (Драгићевић 2015: 162-187), налазећи се на њиховом споју, не бивајући окренута

7 У Речнику српског језика дефиниција одреднице Балкан гласи: 1. планински систем веначних планина у источној Србији и Бугарској. 2. Балканско полустрво (које се налази у југоисточној Европи између Црног, Мраморног, Егејског, Јонског и Јадранског мора) (РСЈ 2011: 59, в. Балкан). 
довољно ниједној страни да би јој безрезервно и припадала, баш као и Балкан, који је зато на „ветрометини”, што је податак који нуде и одговори на прво питање.

Питање број 2. Испитаници су замољени да, замишљањем типичног Балканца, пруже податке о његовим типичним особинама и стањима. Питање на које је требало дати одговор је: „Како типичан Балканац изгледа психички и физички?"

На основу одговора које су испитаници пружили, добијен је материјал помоћу којег се може реконструисати прототипични Балканац, те увидети како се на датом прототипу гради стереотип о представнику народаิ. ${ }^{8}$ Добијени одговори одликују се значајном бројношћу и разноликошћу, те ће се примаран фокус усмерити на десет најфреквентнијих. Добијени низ података своди реконструкцију Балканаца у дискурсу саговорника на 10 кључних особина: висок 46, снажан 33, крупан 22, тврдоглав 20, весео 13, упоран 13, ирн 12, јак 12, леп 11, инатан 10. Највећи број испитаника сматра да припадника балканских народа одликује значајна ФИЗИЧКА проминентност и да у истакнутости своје снаге и висине он бива носиоцем приметне лепоте. Такође, говорници су се изјаснили да се Балканац у свом односу према раду истиче упорношћу, те да односе са другим људима изражава кроз веселост, али и пркос, што такође објашњава високу фреквенцију најизраженије психичке особине, а то је тврдоглавост. За највећи број особина које одликују психу просечног Балканца могло би се рећи да потичу из исте лексичко-семантичке групе, чији се чланови (упоран, инатан, тврдоглав), уз различита семантичка нијансирања, употребљавају када се жели описати особа која остаје при своме, способна је да издржи и истрајава без обзира на савете и услове са стране. Када се сагледа шира слика, испоставиће се да се, поред физичких, највећи број особина везује за ПСИХОЛОШКУ сферу Балканца (тврдоглав 20, весео, упоран 13, инатан 10, храбар 8, психички издржљьив 7). Као најмање фреквентни (појављују се једном до три пута), али не и најмање важни, јер су махом везани за негативан психолошки аспект, јављали су се придеви: иизофрен, депресиван, несигуран, импулсиван, истраумиран, ла-

8 Слично као Јежи Бартмињски, а из когнитивно-лингвистичког угла, Људмила Поповић тумачи стереотип као „асоцијативни прототип (тј. туђе искуство у вези са фрагментом екстралингвистичке стварности)". Прототип утемељује у вредносној структури човековог искуства, које он стиче одрастањем одмеравајући властито искуство спрам стварности у којој се налази. Касније ће, а ту се нарочито издваја снага медија, стереотип који нам намеће ауторитет преузети улогу прототипа у начину на који појмимо стварност. Ако говорник нема когнитивно устоличен прототипичан образац на који се може ослонити у перцепцији одређене појаве, он ће искористити стереотип чију репрезентативност значења проналази у колективном искуству (Поповић 2008: 63-64). 
комислен, луд, ментално оболео, неуротичан, нариисоидан, затуиан, тупав - одлучан, самоуверен, амбичиозан, искрен, истрајан, паметан. Из сфере СВАКОДНЕВНИХ ОСОБИНА најуочљивији је однос који се реализује између лексема вредан и лењ; обе су се ретко јављале у корпусу, по једном. У ИДЕОЛОШКОМ смислу, три говорника су навела да је типичан Балканац традиционалан, а два да је патријархалан. Коначно, уз психолошки домен, типски је по броју најучесталијих придева активирана сфера ДРУШТВЕНИХ односа. Као социјално биће, Балканац је оличен у низу релативних супротности. Он је добар, гостољубив, Гостопримљив, правичан и толерантан, асертиван, дружељубив, комуникативан и породичан човек. Међутим, он је и напрасит, конфликтан, али и интровертан, према другима нетрпељив, агресиван и свадљив. Као најфреквентније од њих, међусобно се опонирајући на релацији позитивно - негативно, јавиле су се лексеме добар и агресиван (6 одговора) и гостољубив и свадљив (5 одговора).

Физичке и психичке карактеристике и стања прототипичног Балканца инатан: $5,21 \%$

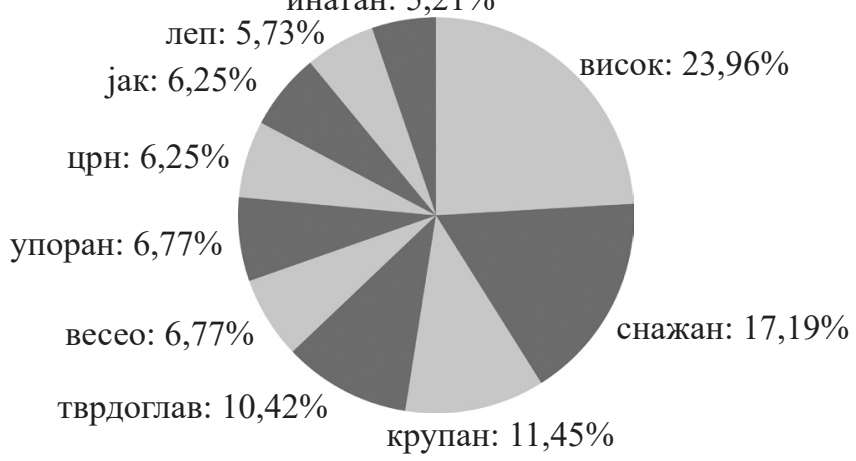

Прилог 1. Десет најфреквентнијих асоцијација на питање: „Како типичан Балканац изгледа психички и физички?”

Питање број 3. Одговором на задатак „Допуни реченицу садржајем којег се прво сетиш: 'Ја живим на Балкану, али ,", очекивано је да, сходно супротном напоредном односу у формално-синтаксичком смислу, та супротност буде истакнута и садржајно, у семантици испитаникове представе која се супротставља садржају првог дела реченице.

Одговори на ово питање смисаоно су врло уједначени и представа Балкана очитана је из уже димензије друштвеног, превасходно егзистенцијално-емотивног и вредносног параметра, те преплитању та два у врло израже- 
ном систему стереотипизације. Стога се сазнаје да - Ја живим на Балкану, али: „ме не одређују кајле, паре и спонзоруше”; „бих га промијенила”; „се ускоро селим надам се”; „ми се то не свиђа”; „нисам типичан Балканац”; „вољела бих да не живим”; „ми је жао што има пуно ратова и беде”; „срамота ме је”; „страхујем од немира који се појављују периодично”; „нисам ни хомосексуалац, ни луд ни глуп”; „нисам насилник и културан сам”; „нисам ксенофобична”; „то није био мој избор”; „нисам насилник и културан сам”; „не мислим да сам типичан житељ Балкана”; „није то лако”; „нисам у потпуности задовољна”; „немам мишљење типичног Балканца”; „побећи ћу одавде првом приликом”; „немам такав менталитет”; „нисам типична Балканка”; „не привлаче ме типични Балканци”. Одговори су у различитом степену негативно вредновани, што није искључив случај са онима из претходног питања, а додатно је изражен степен отклона од претпостављеног стереотипа. Разлог овакве поларизованости може се тражити у томе што се формално, захваљујући супротном везнику као својеврсном дискурсном маркеру, у другом питању испитаник ставља у позицију оцењивања оног Другог, са којим као посматрач споља, може успоставити дистанцу и оцењивати га тако да себе не сматра нужно предметом колективног увида који може бити описиван и евалуиран. С друге стране, формулација овог питања устројава се тако да, ако у претходним одговорима није, овде испитаник себе нужно одређује као предмет оцењивања. Тиме је и његов одговор дат из претпостављене перспективе оног облика стереотипизације којом Други профилише и потврђује „нас” као прототипичне Балканце. Отуда је говорнике сада, срамота, сматрају да нису глупи, нити луди, нису насилници, желе да се одселе са ових простора и, уопште, сматрају да нису „типични Балканци". Ово је место где се Балкан у појмовном метонимијском значењу својих житеља одликује инфериорношћу и комплексом ниже вредности. Испитаници, као географски представници Балкана, читав комплекс пресупонираних особина које спрам себе конфронтирају најчешће појме са друштвеног (жеље да овде не живе, Балканци су ксенофобични и некултурни) и психолошког аспекта (доживљај срамоте, Балканци су луди, глупи и насилни).

Питање број 4. Циљ четвртог питања било је стицање увида у то које појмове испитаници најчешће повезују са Балканом, те да ли се та веза оличава у контрастним или аспектима на нивоу одређених сличности. Овај задатак гласио је: „Допуни задату конструкцију првом именицом које се сетиш: Балкан и '. 
Добијени одговори пружају поприлично неустаљену културолошку слику у погледу појмова које говорници меморијски складиште заједно. Три научесталија су: Европа (14), свет (9) и Србија (6). Први најфреквентнији одговор потврђује да се између Балкана и Европе успоставља одређена парадигматска веза неусловљена семантичким, нити уопште лингвистичким фактором. ${ }^{9}$ Слично би се могло тврдити и за свет. Навођење реакција Европа (14), Србија (6), Турска (2), Медитеран, Балкан, Русија и Дунав (1) иду у прилог теорији о заједничком складиштењу појмова са јединственом функцијом - именовање географских појмова. Спорадично се, што није био у случај у претходним одговорима, појављивао онај који упућује на везу између назива планине Балкан и планине уопште. Уз то се спомињу и планина (2), река и полуострво (1), такође као истакнути представници ГЕОГРАФСКЕ номенклатуре. Остали аспекти, који су се у грађи јављали једном до двапут, одређени су још и посредством општијих критеријума који се могу разврстати у:

СВАКОДНЕВНЕ: храна, ћевапи, бурек, месо, кафана, провод, кошарка, ритам, балкон, весеље, изобиље, ракија)

КУЛТУРНЕ: музика

ФИЗИЧКЕ: лепота, снага

ИДЕОЛОШКЕ: Диктатура, Исток, традиција ${ }^{10}$

ПОЛИТИЧКЕ: Политика, рат, ратови, нереди

ПСИХОЛОШКЕ: мржњ а, севдах, страх, љубав, неизвесност, снови

ДРУШТВЕНЕ: жена, жене, добри људи, шарм, малограђанство, јединство

ИДЕНТИТЕТСКЕ: $а$, , ми, остали, сви остали, други, Срби, Балканщи

РЕЛИГИЈСКЕ: хришћанство

ОСТАЛЕ (у статусу експресивних семантичких компонената): буре барута, недођија, авлијска авет.

Питање број 5. У овом питању тражено је од испитаника да допишу прву именицу која им падне на памет, а иза поменутих придева: „Допуни конструкцију првом именицом које се сетиш: балкански, -ска, -ско ”. Тиме, на основу синтагматских спојева, дају податке о најчешћим асоцијативним везама између придева и именичког појма на који се

9 Идентичан резултат пронађен је у Асоцијативном речнику српскога језика, о чему ће бити речи у наставку.

10 Сходно лингвокултуролошкој анализи Маријане Богдановић о концепту Европа, коју говорници третирају високо на својој вредносној скали и представљају је као својеврстан идеал квалитетног живота, одговор Европа би се такође могао сврстати у категорију идеолошког (Богдановић 2015: 98-124). 
придев односи. Именице из анкете су: менталитет (27); полуострво (9), живот (7), инат (5); рат, ратови (4); ипијун (3);"11 народ, ьуди, храна, народи (2); богатство, планине, Понос, чудо, патриотизам, дете, човек, посао, отпор, галиматијас, житељи, кухиња, мушкарач, предео, међа, култура, трагедија, савез, „елита”, мерак, регија, лепота, музика, орао, коло, мафија, момии, нарав, нација, породица, сир, јело, круг, нога, хумор, море, посла, правила, иарм, хаос, сиромаштво, улица, сценарио, национализам, јунак, уједињеност (приликом невоља) (1).

Именице са којима придев балкански/а/о најчешће доспева у синтагматски спој

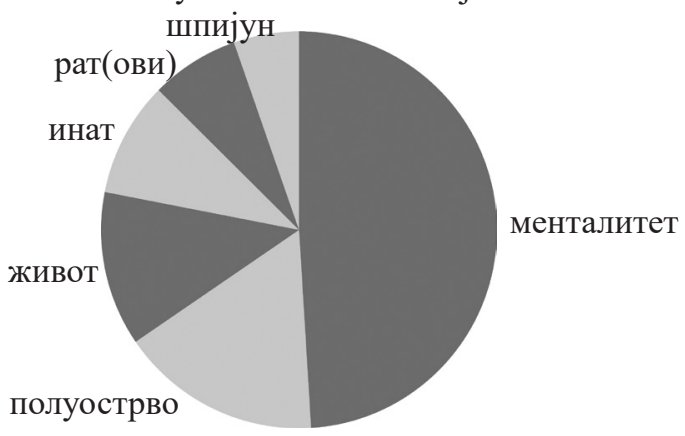

Прилог 2. Шест најучесталијих одговора у синтагматском споју балкански,

$$
-c \kappa a,-c \kappa о
$$

Примењена метода дописивања именица којих се говорници брзо сете, не размишљајући постоји ли пожељан одговор, с обзиром да за анализу пожељан одговор јесте управо онај који наведу - омогућује увид у фонд представа које испитаници имају о појму чија је типична квалификација балканско. Према овим анкетним подацима може се видети да доминира представа о значају СВАКОДНЕВНИЦЕ и ДРУШТВЕНИХ односа, и то ако се говори о типској разноликости одговора добијених у тим двема категоријама. Шеснаест типова одговора испитаници су дали из оквира свакодневних феномена, где се упечатљиво издваја однос према храни (храна, мерак, јело, живот, хаос, кухиња, орао, сиромаштво, богатство, улица, човек, сир, нога, људи, трагедија, житељи), а једанаест типова одговора из домена социјалних аспеката (мафија, хумор, уједињеност, народ, дете, момци, породица, галиматијас, мушкараи, „,елита”, шарм). Па ипак, ове бројеве надилази бројчано истакнут одговор,

11 Синтагма балкански шпијун овде упућује на познату драму Душана Ковачевића Балкански шпијун, касније и истоимени филм из 1984. године, у режији Душана Ковачевића и Божидара Николића. 
лексема менталитет као најфреквентнија. Очигледно, питање менталног склопа је у свести српских говорника посебно истакнуто као диференцијална особина балканских етничких група и битан спецификум у односу на Другог. Уз менталитет су се, у сфери ПСИХОЛОШКОГ, издвојили и инат, понос и нарав, који смисаоно корелирају са резултатима из одговора на друго питање, и самим тим, учвршћују свест о идеји сопствене вредности као препознатљивог обележја диксурзивних представа. У контексту ИДЕОЛОГИЈЕ, као специфично балкански издвојили су се патриотизам, нащија, јунак и нащионализам. КУЛТУРНИ делокруг покривају лексеме музика, међа, ${ }^{12}$ култура и коло.

Питање број 6. Последње питање имало је форму: „Допуни конструкцију првим глаголом у инфинитиву којег се сетиш: као на Балкану”. Да би се добили резултати о типичним, препознатљивим активностима и стањима које испитаници везују за балкански простор, затражено је да у празан простор упишу глагол у инфинитивном облику. Одговори су били следећи: живети (17); ратовати (8); уживати, веселити се (7); радити (6); пити (5); волети, јести (4); мрзети, певати, играти, славити, свађати се (3); радовати се (2); кафенисати, осуђивати, стрепити, одрастати, напити се, дружити се, бринути, умирати, пушити, намучити се, забављати се, животарити, газити, мучити се, страдати, кувати, инатити се, парадирати, викати, волети, војевати, проводити се, блејати, заиграти, умрети, јамчити, борити се, преживети, дисати (1).

Активности и стања препознатљиви за живот на Балкану

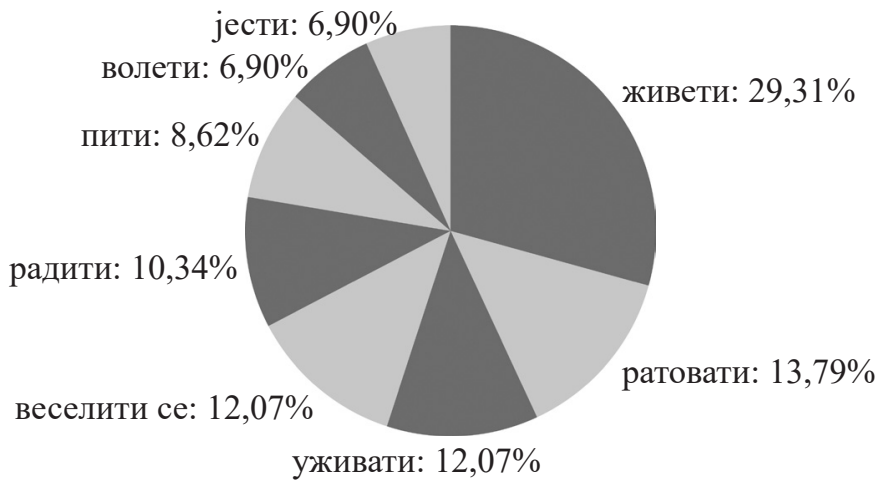

Прилог 3. Осам најфреквентнијих глагола-асоцијација као одговор на конструкцију , као на Балкану".

12 Балканска међа је руско-српски филм из 2019. године. Режирао га је Андреј Волгин, а филм је публици предочен и у форми мини-серије. 
Приметна је значајна разуђеност у бројности одговора које су испитаници наводили. Ипак, као најучесталији издваја се живети, а једанаест од седамнаест говорника који су се определили за овај одговор нешто одређеније су објаснили разлог за дату конструкцију. Ова објашњења, иако нису експлицитно захтевана од стране испитивача, била су изузетно значајна јер су дефинисана посредством неких од преосталих глагола добијених у збиру. Најпре, јасно је да представници нашег народа сматрају да постоји карактеристичан животни образац. Домен у ком се он огледа испитаници виде у чињеници „да се на Балкану често ратује”, што, не случајно, одговара управо следећем глаголу по учесталости. Сматрају такође да је живот на балканским просторима обележен „свађањем”, „мучењем”, да се на Балкану „умире” и страда". Па ипак, говорници су наводили да се специфично живи и зато што се нигде као на Балкану „не једе”, „не весели”, „не игра”, „не пева”, те да су Балканци познати као „борбени људи”. Снажна супротстављеност у тумачењима ствара слику о Балкану као феномену утемељеном на иако подвојеној, ипак евидентно одрживој целини која опстаје упркос егзистенцијалној угрожености, тиме што се на њу одговора радњама које на својеврстан начин славе живот са̂м. Подсећања ради, као трећи одговор по фреквенцији у претходном питању издвојила се управо именица живот. Високу фреквенцију глагола живети немогуће је не тражити у егзистенцијалној бојазни и друштвено-историјским, пре свега политичким околностима, чијом изменом набоље би се можда у даљој временској перспективи могао мењати концепт живота на Балкану, а таква измена би очекивано могла наћи и своју одговарајућу језичку интерпретацију.

\section{7. Стимулус Балкан у Асоцијативном речнику}

Погодан начин за употпуњавање слике о Балкану јесте и анализа асоцијативног лексикона, који се налази у Асоцијативном речнику српског јези$\kappa a$, и за који је грађа скупљана током 2002/2003. године. Према његовим подацима, десет најфреквентнијих асоцијација на задати стимулус биле су лексеме полуострво (78), експрес (67), рат (53) Србија (52), буре барута (36), земља (34), Југославија (18), ратови (15), Европа (13), биоскоп (10). Подаци сведоче о значају синтагматских асоцијативних веза које се као најјаче остварују у спојевима између именице и придева, и то у овом случају придева који је творен од именице-стимулуса. На сличан начин стимулус гради однос са асоцијативном лексемом експрес, чија се појава овде може образ- 
ложити значајношћу истоименог југословенског филмског феномена. ${ }^{13} \mathrm{y}_{3}$ то је биоскоп јасна асоцијација на некадашњи београдски филмски театар, који је у доба сакупљања грађе и даље био отворен. У контексту географског именовања, уз лексему полуострво као најучесталије јављају се и Србија, Југославија и Европа, са, делује, различитим третманом концептуализације. Наиме, концептуализација прва два појма, који се односе на називе прототипичних балканских земаља према схватању говорника, базирана је на чињеници да је Балкан својеврстан просторни садржалац географских ентитета на које асоцира. У односу пак између Балкана и Европе види се међулексемно опонирање, према коме ове две лексеме ступају у однос својеврсне „културолошке антонимије”. ${ }^{14}$ Према резултатима из истог речника са стимулусом Европа, неки од закључака о начину концептуализације овог појма код испитаника јесу такви да се Европа поима као нада у боље сутра и доводи у синонимску везу са напредношћу, моћи, слободом (Богдановић 2015: 114). На вредносној скали друштва које доживљава Европу позиционираном на врху, концепт Балкана са својим преосталим реакцијама рат, ратови и буре барута, где последња синтагматска јединица гради асоцијативну везу и са претходне две лексеме (Балкан као жариште ратних збивања) - смештен је сасвим ниско. Могућност да се овај аксиолошки аспект додатно осветли пружају преостале асоцијације, при чему бројност негативних схватања (нестабилност, примитивизам, крв, неслога, пропаст, заостао, бедан, брука, расуло, сировост, затуцаност, криминал, назадност, немири, ђубриште, одсуство среће, тероризам, лоше, луд) у потпуности превазилази понеки позитиван доживљај (земља из снова, храброст, обећана земља, родољуби).

\section{8. Закључне напомене}

У овом раду је анализиран концепт Балкан у савременом српском језику и култури помоћу анкетних података (анкета се састојала од шест питања, на које је одговарало 114 испитаника, а у истраживању се осврнуло и на по-

13 Балкан експрес је југословенски филм из 1983. године, настао по сценарију Гордана Михића и под редитељском палицом Бранка Балетића.

14 Према Обратном асоиијативном речнику, Балкан је био најчешћа реакција управо на ова три стимулуса (Југоставија 14, Србија 6, Европа 4), уз именицу груди, чиме се реферише на култну југословенску песму Груди балканске (1997), групе Последња игра лептира. Чини се да је бројчана значајност како стимулуса тако и реакције Југославија у међувремену почела ишчезавати, а разлоге за то се изнова проналазе у сада већ скоро дводеценијској дистанци у односу на време прикупљања речничке грађе, као и чињеници да за велики број млађе популације испитаника концепт Југославије има мањи вредносни значај. 
датке из Асоцијативног речника). Примењена техника прикупљања података у овом истраживању био је упитник, а добијени материјал у виду вербалних асоцијација био је подвргнут дескриптивној, примарно квалитативној, анализи. На основу резултата из упитника, представа о појму Балкана се актуализовала и тиме се омогућио одређен осврт на асоцијативни комплекс говорника српског језика. Резултати нису јединствени, већ су утемељени на значајним подвојеностима. Испитаници најчешће истичу доживљај неприпадања - како Балкана у односу са светом тако и говорника у односу са Балканом, нарочито у сфери бивања типичним Балканцем. Међутим, у базичном садржају особина кроз које се материјализује стереотип етничких група истиче се и снажно позитивно вредновање особе која је весела и издржљива, привлачног физичког изгледа. Специфичност менталитета и начина живота посебно се истичу кроз аспект опште препознатљивости. Менталитет је према најфреквентнијим одговорима добијеним у анкети првенствено обележен својеглавошћу. Животна пракса је аморфно конципирана и често прожета тескобама и мучењем, упркос којима се и даље опстаје. Тескобе су нарочито ратне природе и тај доживљај је врло изражен у честој употреби експресивне конструкције буре барута у најразличитијим асоцијативним побудама (јавља се као реакција у Асоцијативном речнику и као један од појмова са којим се концепт Балкан најчешће заједно складишти у свести говорника, што је примећено у формирању напоредних конструкција у четвртом и описивања суштине Балкана у првом питању). Концепт Балкан, испоставља се, сведен је на низ супротстављених особина. У вредносном коду испитаника он не припада категорији компактних концепата, иако нагиње ка непожељно оцењеном. Изопштен од могућности да буде културолошки концептуализован искључиво у својеврсној, ако не надмоћи, онда свакако равноправној конкуренцији у погледу степена цивилизацијског развитка спрам остатка света, оличава се у натегнутом односу између пожељног и непожељног. С једне стране, јавља се као симбол нецивилизованог, културолошки оличен у колективном доживљају варварског и инфериорног. С друге стране, присутан је као симбол издржљивог, самосвојног и опстајућег. Савремени друштвени и политички токови нису потпуно угасили свест о географској компоненти појма, али тамо где су развијали себи својствен утицај, он би за резултат дао став који је производ различитих идеологија и субјективности појединца. Може се рећи да је општа перцепција појма Балкан скуп разнородних елемената, чија се природа може мењати под утицајем различитих ванјезичких фактора, увек остајући, лингвокултуролошки 
посматрано, детерминисана значајем који може имати за човека. Дакле, анализа асоцијативног дискурса на задатом материјалу изнедрила је концепту Балкан статус лингвокултуреме, у систему тријадне дефиниције коју примарно чине географски, културолошко-религијски аспект и аспект који се односи на опште особине лица која на датом географском простору живе, што има своје оправдање у појмовно метонимијском контексту. Скуп тих карактеристика налази се примарно у психофизичким особеностима, којима се придодају идеолошка одређења, као и она заснована на социјалној интеракцији. Егзистенцијални оквир, који битно утиче и на сам начин живота, третира се као споља често угрожен, јер досадашња политичка, историјска и друга друштвена искуства дају солидно поткрепљење за такву мотивацију у свести испитаника̂. Као резултат добија се лексема (прецизније лингвокултурема) која у својој конотативној макрокомпоненти значења садржи високо позиционирану вредносну компоненту корисну за потребе исказивања експресивних квалификација.

\section{ЛИТЕРАТУРА}

APCJ 2005: П. Пипер, Р. Драгићевић, М. Стефановић, Асоиијативни речник српскога језика. Београд: Београдска књига-Службени лист СЦГ Филолошки факултет у Београду.

Бартмињски 2011: Ј. Бартмињски, Језик - слика - свет: етнолингвистичке студије. Београд: SlovoSlavia.

Богдановић 2015: М. Богдановић, О концепту Европа у савременом српском језику и култури. У: Дејан Ајдачић (ур.), О вредностима у српском језику: зборник етнолингвистичких радова, Београд: Алма, 98-124.

Бугарски 2005: Р. Бугарски, Језик и култура. Београд: Библиотека XX век. Вуловић 2015: Н. Вуловић, Српска фразеологија и религија:

лингвокултуролошка истраживања. Београд: Институт за српски језик САНУ.

Драгићевић 2017: Р. Драгићевић, Лексикографски трагови језичких и културолошких контаката Срба са другим народима у XIX веку. Исходишта, 3, 99-108.

Драгићевић 2015a: Р. Драгићевић, Концепт слобода у српском језику и култури. У: Дејан Ајдачић (ур.), О вредностима у српском језику: зборник етнолингвистичких радова, Београд: Алма, 53-72. 
Драгићевић 2015б: Р. Драгићевић, О концептима Истока и Запада у српском језику. У: Дејан Ајдачић (ур.), О вредностима у српском језику: зборник етнолингвистичких радова, Београд: Алма, 162-187.

Драгићевић 2014: Р. Драгићевић, Ка лингвокултуролошком речнику српског језика. Научни састанак слависта у Вукове дане, 43/1, 247-263. Драгићевић 2011: Р. Драгићевић, Лингвокултуролошки приступ у настави српског као страног језика. У: Весна Крајишник (ур.), Српски као страни језик у теорији и пракси II: тематски зборник радова, Београд: Филолошки факултет, 81-95.

Драгићевић 2010a: Р. Драгићевић, Вербалне асоцијаџије кроз српски језик и културу. Београд: Друштво за српски језик и књижевност Србије. Драгићевић 2010б: Р. Драгићевић, Лексикологија српског језика. Београд: Завод за уџбенике.

Драгићевић 2010в: Р. Драгићевић, Лингвокултуролошка упоредна истраживања етнокултурних стереотипа. Анали Филолошког факултета, 22, 201-214.

Ивић 2001: М. Ivić, Pravci u lingvistici. 1. Beograd: Biblioteka XX vek. Илић и Ђурић Миловановић 2013: М. Илић, А. Ђурић Миловановић, Коме треба антрополошка лингвистика у Србији данас? Пример креирања Дигиталног звучног архива Балканолошког института САНУ. Етнолошко-антрополошке свеске 21, (н.с.) 10 [Online], 73-89, [https:// dais.sanu.ac.rs/bitstream/handle/123456789/8144/Ilic_Marija_Duric_Milovanovic_Aleksandr.pdf?sequence=1\&isAllowed=y].

Илић 2002: М. Илић, Etnolingvistika u Srbiji. Zbornik Matice srpske za slavistiku [Online], 62, 211-234, [https://dais.sanu.ac.rs/bitstream/handle/123456789/8451/Ilic_Marija_Etnolingvistika_u_Srbiji_Et.pdf?sequence $=1 \&$ isAllowed $=\mathrm{y}]$.

Кребер и Клакхон 1952: A. L. Croeber and C. Cluckhohn, Culture: a critical review of concepts and definitions. Massachusetts: Harvard University. Мазовер 2003: M. Mazover, Balkan: kratka istorija. Beograd: Alexandria Press. Маслова 2010: В. А. Маслова, Лингвокульогия. Москва: Академия.

Милосављевић 2021: Т. Милосављевић, Дијалекатска слика света као лингвокултуролошки феномен. Научни састанак слависта у Вукове дане, 50/1, 213-221.

Мршевић-Радовић 2008: Д. Мршевић-Радовић, Фразеологија и начионална култура. Београд: Друштво за српски језик и књижевност Србије. 
Мутавџић 2013: П. Мутавџић, Балкан и балканологија: Увод у студије Југоисточне Европе. Београд: Чигоја штампа.

Новокмет 2020: С. Новокмет, Називи животиња у српском језику: семантичка и лингвокултуролошка наализа. Београд: Институт за српски језик САНУ.

OАРCЈ 2011: П. Пипер, Р. Драгићевић, М. Стефановић, Обратни асоиијативни речник српскога језика. Од реакиије ка стимулусу. Београд: Београдска књига - Службени гласник.

Пејановић 2015: A. Pejanović, Sintaksa, semantika i lingvokulturologija komparativnih frazeologizama. Banjaluka: Panevropski univerzitet Apeiron.

Попадић, Павловић и Жежељ 2018: D. Popadić, Z. Pavlović i I. Žeželj, Alatke istraživača: metodi i tehnike istraživanja u društvenim naukama. Beograd: Clio.

Поповић 2008: Lj. Popović, Jezička slika stvarnosti: kognitivni aspekt kontrastivne analize. Beograd: Filološki fakultet.

Ристић и Лазић Коњик 2020: С. Ристић, И. Лазић Коњик, Когнитивни праваи у српској етнолингвистици - почеци развоја и актуелни проблеми. Београд: Институт за српски језик САНУ.

Ристић 2004: С. Ристић, Експресивна лексика у српском језику: теоријске основе и нормативно-културолошки аспекти. Београд: Институт за српски језик САНУ.

PCJ 2011: Речник српског језика. Нови сад: Матица српска

Сикимић 2012: Б. Сикимић, Тимски теренски рад Балканолошког института САНУ: Развој истраживачких циљева и метода. У: Ивановић, Баришић, Милина (ур.) Теренска истраживања - поетика сусрета, Београд: Етнографски институт САНУ [Online], 167-198, [https://www. biljanasikimic.com/pdf/bs_r_2005_izazov_terenskog_rada.pdf].

Сикимић 2006 [2007]: Б. Сикимић, Етнолингвистика у Србији: од реконструкције културе до теренских истраживања. Свет речи 23-24 [Online], 37-42, [https://www.academia.edu/2099737/_23-24_2006_2007_37-42].

Сикимић 2005: Б. Сикимић, Изазов теренског рада - етнолингвистика или антрополошка лингвистика?. Зборник радова Етнографског института САHУ, 21 [Online], 235-245, [https://www.biljanasikimic.com/pdf/ bs_r_2005_izazov_terenskog_rada.pdf].

Тодорова 1999: M. Todorova, Imaginarni Balkan. Beograd: Biblioteka XX vek. Толстој 1995: Н. Толстој, Језик словенске културе. Ниш: Просвета. 


\title{
Milica Škorić
}

\section{THE CONCEPT BALKAN IN THE MODERN SERBIAN LANGUAGE AND CULTURE}

\begin{abstract}
Summary
The subject of this paper is the linguo-cultural analysis of the Balkan concept. The research was conducted on the basis of associative data obtained by a survey. The aim of the research is to provide one of the possible insights and reviews on how the concept of the Balkans is conceptualized in the modern discourse of Serbian speakers. Paper shows that this concept is defined very polarized in the consciousness of Serbian speakers and that the reasons for that should be sought primarily in the non-linguistic factors that define Serbian culture.
\end{abstract}

Keywords: Serbian, linguoculturology, survey, word association method, Balkan. 